\title{
A Viral Pathogen from Pine Processionary Moth, Thaumetopoea pityocampa (Denis \& Schiffermuller, 1775) (Lepidoptera: Notodontidae)
}

\author{
Mustafa Yaman ${ }^{1, *}$
}

(1) Bolu Abant İzzet Baysal University, Faculty of Arts and Science, Department of Biology, TR- 14030 Bolu, Turkey

* Correspondence: e-mail: muyaman@hotmail.com
Citation: Yaman M, 2021. A Viral Pathogen from Pine Processionary Moth, Thaumetopoea pityocampa (Denis \& Schiffermuller, 1775) (Lepidoptera: Notodontidae). South-east Eur for 12(1): 67-70. https://doi.org/10.15177/ seefor.21-07.

Received: 27 Jan 2021; Revised: 6 Mar 2021; 30 Apr 2021; Accepted: 5 May 2021; Published online: 24 May 2021

\begin{abstract}
Pine processionary moth, Thaumetopoea pityocampa (Den. \& Schiff.) is a serious defoliator in pine forests. Its larvae cause defoliation by eating leaves mainly on coniferous species, Pinus brutia, P. nigra, P. pinaster, and P. pinea in Turkey. Cypovirus is the most common entomopathogen in T. pityocampa populations. In this study, the ultrastructure of the cypovirus of $T$. pityocampa was observed in the intestine lumen of the predatory beetle, Calasoma sycophanta L. (Coleoptera: Carabidae), which supports the hypothesis of possible transmission of the virus to T. pityocampa populations by the predatory beetle. Polyhedral occlusion bodies (OBs) and virions were examined by electron microscopy. OBs of the virus were of irregular shape and $2.1 \mu \mathrm{m}(1.2-3)$ in diameter, and each of them included up to 50 virions in a cross-section. Virions were icosahedral and $78.3(65-90) \mathrm{nm}$ in size and each virion had surface spikes. Smaller OBs, larger virions and a high number of virions per cross-section were the main features of the cypovirus in T. pityocampa. Our observations make us conclude that the predator beetle, $C$. sycophanta, may disseminate $\mathrm{OBs}$ of cypovirus when preying upon infected T. pityocampa larvae.
\end{abstract}

Keywords: predatory beetle; Calasoma sycophanta; cypovirus; prey; transmission; biological control

\section{INTRODUCTION}

While insects have many beneficial roles in research (Takov et al. 2020), medicine and agriculture (Demirözer et al. 2020), the number of different plant-damaging insects is considerably high (Kanat et al. 2005, Erkan 2018, Kuyulu and Genç 2020, İnal and Kandemir 2020). Pine processionary moth, Thaumetopoea pityocampa (Den. \& Schiff.), is native to southern Europe, North Africa and parts of the Middle East. This pest extends its geographical distribution, currently ranging from North Africa to central Europe (de Boeer and Harvey 2020). Its larvae cause defoliation by eating leaves mainly on coniferous species, Pinus brutia, $P$. nigra, $P$. pinaster, and $P$. pinea in Turkey (Atakan 1991, Kanat et al. 2005), as well as central in southern Europe and North Africa (Trematerra et al. 2019). Climate change stimulates the pine processionary moth caterpillars to increase their attacks in pine forests (Hodar et al. 2003). The processionary moth defoliation can have a significant impact on the growth rate of the infested trees by decreasing the activity of needles and their availability for photosynthesis (Hodar et al. 2003, Jacquet et al. 2012, Erkan 2018). The effect of defoliation on tree growth occurs not only in the current year but also over years. Erkan (2018) determined the five-year effect of defoliation on the tree growth in Pinus brutia forests and found significant relationship between added total defoliation rate and total diameter for five years. According to this study, defoliation in trees damaged by T. pityocampa has increased, and diameter growth loss rate also has also increased significantly. Jacquet et al. (2012) found that mean relative tree growth loss increased with the rate of defoliation under the processionary moth attack and the damage was significantly higher for young trees than for old trees. Repeated defoliation weakens trees and makes them 
more susceptible to secondary pests such as bark beetles and may result in death of trees (Jacquet et al. 2012). T. pityocampa also causes the health risks to people, pets and livestock due to their urticating hairs (Trematerra et al. 2019). Possible treatment options include chemical pesticides application, mechanical removal, use of predator insects and entomopathogenic organisms (Kanat and Özpolat 2006, Goertz and Hoch 2013). However, the chemical pesticides used can harm people and the environment as well as nontarget organisms (Arıkan and Turan 2020). The predatory beetle Calosoma sycophanta L. (Coleoptera: Carabidae) has been used for the biological control of $T$. pityocampa in Turkey (Kanat and Özpolat 2006). Currently this beetle is mass produced in 35 rearing laboratories and released for biological control of $T$. pityocampa in different regions in Turkey (Ceylan et al. 2012).

In the pest control strategies against T. pityocampa larvae, chemical insecticides are mainly used. Entomopathogenic microorganisms such as viruses, bacteria, protists, fungi and nematodes are promising for pest control (Avtzis 1998, Er et al. 2007). Although cypovirus (Cytoplasmic Polyhedrosis Virus (CPV)) is the most common entomopathogen in $T$. pityocampa populations (Tsankov et al. 1979, Ince et al. 2007), studies on this pathogen are very limited.

In this study, the ultrastructure of the cypovirus of $T$. pityocampa observed in the intestine lumen of the predatory beetle, $C$. sycophanta, has been documented for the first time. Furthermore, the infection was confirmed in the $T$. pityocampa larvae, and the virus was compared with cypovirus recorded previously in T. pityocampa as well as other lepidopteran pests to support the hypothesis that the transmission of the virus in T. pityocampa populations by the predatory beetle is possible.

\section{MATERIALS AND METHODS}

C. sycophanta adults and T. pityocampa larvae were collected in the rearing laboratories in Agean and Mediterranean region of Turkey. Samples of both insects were dissected in Ringer's solution (Merck) for microscopic examination according to Yaman (2019). The midgut lumen of $C$. sycophanta and the different organs such as intestine, fat body, hemocoel and Malpighian tubules of $T$. pityocampa were examined for the occlusion bodies (OBs) of $T$. pityocampa cypovirus. When OBs were observed, part of intestinal material or infected tissues was used for ultrastructural studies. Ultrastructural studies were carried out according to Yaman and Radek (2019). Characteristics of the viral particles from both insect species were compared to confirm that the virus in the midgut lumen of $C$. sycophanta shows the same characteristics as T. pityocampa cypovirus.

\section{RESULTS AND DISCUSSION}

A cypovirus was observed in the midgut lumen of the predator beetle $C$. sycophanta that was reared with the larvae of T. pityocampa, and in the gut tissue of dead T. pityocampa larvae showing typical viral infection symptoms. OBs and virions were examined by electron microscopy (Figure 1). Polyhedral occlusion bodies (OBs) were of irregular shape (Figure 1a, b) and $2.1 \mu \mathrm{m}(1.2-3)$ in diameter and each of them included up to 50 virions in a cross-section (Figure $1 \mathrm{c}$ ). Virions were occluded by a deposition of a polyhedrin matrix (OB) (typically up to 50 virions per $O B$ ) (Figure $1 \mathrm{a}, \mathrm{b}$ ). Virions were icosahedral and $78.3(65-90) \mathrm{nm}$ in size (Figure 1c) and each virion had surface spikes (Figure 1d).

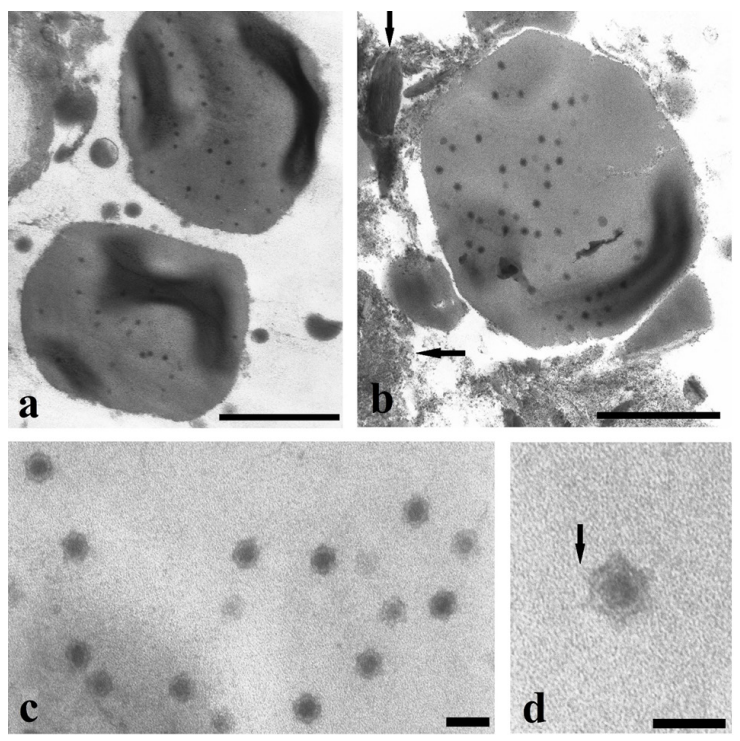

Figure 1. Ultrastructure of polyhedral occlusion bodies (OBs) of a cypovirus (CPV) of T. pityocampa; (a) Two occlusion bodies including different virions in a cross-section; (b) A whole inclusion body including up to 50 virions in a cross-section, surrounded by intestinal nutrient residues (arrow indicates); (c) A number of icosahedral virions occluded in polyhedrin matrix. (d) A virion exhibiting surface spikes (arrow indicates). Bars: $1 \mu \mathrm{m}$ (Figure 1a, b) and $100 \mathrm{~nm}$ (Figure 1c, d). 
The cypovirus of $T$. pityocampa has been recorded in a number of studies from different countries, as a possible microbial pathogen against T. pityocampa (Tsankov et al. 1976, Sidor et al. 1982, ince et al. 2007). However, no detailed ultrastructural studies of this virus were published. İnce et al. (2007) analyzed a cypovirus from T. pityocampa by light and electron microscopes and electrophoretic RNA genome. Unfortunately, that study does not include any ultrastructural characteristics. Cross-sections of OBs in this study showed that they contain a high number of virions (up to 50) (Figure $1 \mathrm{a}, \mathrm{b})$. A high number of virions per OBs is desirable to control pest insect populations. All cypoviruses have similar tissue specifications, infecting only gut of insects. Therefore, shape and size of $\mathrm{OBs}$ and virions, and the number of the virions per $\mathrm{OB}$ are important morphological and ultrastructural characteristics to compare cypoviruses by adding more supportive data to molecular and biochemical comparison. In the literature, ultrastructural characteristics of some cypoviruses of lepidopteran pests have been documented. In order to characterize the T. pityocampa cypoviruses, we compared its morphological and ultrastructural features with other cypoviruses from lepidopteran pests. İnce et al. (2007) noted that the OBs of cypovirus isolated from $T$. pityocampa had larger size, $2.4 \times 5.3 \mu \mathrm{m}$. Zeddam et al. (2003) observed relatively small OBs (between 1 and $3 \mu \mathrm{m}$ ) in Norape argyrrhorea, and Zhou et al. (2014) recorded similarly sized OBs in Dendrolimus punctatus, approximately $1.2 \mu \mathrm{m}$.

The results confirmed that the cypovirus in this study has considerably smaller OBs than that recorded from the same host by ince at al. (2007). However, it has bigger OBs than those of $N$. argyrrhorea (Zeddam et al. 2003) and D. punctatus (Zhou et al. 2014). The cypovirus shows differences also in the diameter $(78.3 \mathrm{~nm})$ of virions from the cypovirus (70 nm) of N. argyrrhorea (Zeddam et al. 2003) and the cypovirus (50 nm) of D. punctatus (Zhou et al. 2014). As a result of the study, smaller OBs, larger virions and a high number of virions per cross-section were the characteristics of the cypovirus in T. pityocampa from different localities. Some strains of virus isolated from different localities may present better insecticidal activities (Murillo et al. 2001).

During the microscopic observation of this study, the cypovirus was observed firstly in the gut lumen of one predator beetle, $C$. sycophanta, and then confirmed in the larvae of the prey, T. pityocampa. As seen in Figure $1 a, b$, the occlusion bodies were not disturbed by the gut contents of the predatory beetle. Entomopathogenic organisms transmit in different ways between insects populations (Yaman 2020). This result speculates that the predator beetle, C. sycophanta, disseminates $\mathrm{OBs}$ of cypovirus when preying upon infected
T. pityocampa larvae. Similar judgments were proved by Capinera and Barbosa (1975), Vasconcelos et al. (1996) and Goertz and Hoch (2013). Capinera and Barbosa (1975) found that field-collected or laboratory-fed C. sycophanta adults defecated nucleopolyhedrovirus polyhedra in sufficient quantity to infect $3^{\text {rd }}$-stage gypsy moth Lymantria dispar (Lepidoptera: Lymantridae) larvae. Vasconcelos et al. (1996) showed that carabids transmit sufficient baculovirus into the soil to cause death in larvae of the cabbage moth Mamestra brussicae L. (Lepidoptera: Noctuidae). Goertz and Hoch (2013) demonstrated that $C$. sycophanta can disperse viable spores of the microsporidian species, Nosema lymantriae and Vairimorpha disparis. Furthermore, they observed that both microsporidian species did not infect the beetles after feeding on infected prey.

\section{CONCLUSION}

Shape and size of OBs and virions, and the number of virions per $O B$ are important morphological and ultrastructural characteristics to compare cypoviruses by adding more supportive data to molecular and biochemical comparison. As a result of the study, smaller OBs, larger virions and a high number of virions per cross-section are the characteristics of the cypovirus in T. pityocampa from a different geography of Turkey. Turkey is a potential source of new and interesting entomopathogens. Observations of this study make us conclude that the predator beetle, $C$. sycophanta, may disseminate OBs of cypovirus when preying upon infected T. pityocampa larvae and therefore play a role in the transmission success of the pathogen. Future studies should be focused on the role of the predator beetle in the transmission of the virus in T. pityocampa populations.

\section{Author Contributions}

MY designed the research, collected the samples, carried out microscopic analysis and wrote the manuscript.

\section{Funding}

A part of this study was financially supported by the Scientific and Technological Research Council of Turkey (TÜBITAK, research project; 1140722).

\section{Conflicts of Interest}

The author declare no conflict of interest.

\section{REFERENCES}

Arıkan TK, Turan SL, 2020. Organochlorine pesticide residues in feathers of four bird species from western part of Turkey. Turk J Zool 44: 401-407. https://doi:10.3906/zoo-2005-52.

Avtzis ND, 1998. The use of Bacillus thuringiensisagainst Thaumetopoea pityocampa Schiff. (Lepidoptera: Thaumetopoeidae) in Greece. In: Proceedings of Population Dynamics, Impacts and Integrated Management of Forest Defoliating Insects, USDA Forest Service, General Technical Report NE-247, 311-316.
Atakan A, 1991. Biology of harmful insects of Forests in Turkey. Forest General Directorate Publication.

Ceylan S, Argun N, Cengiz N, 2012. Avcı böcek Calosoma sycophanta (Coleoptera: Carabidae)'nın yetiştirilmesinde Spodoptera littoralis'in kullanım olanaklarının belirlenmesi. İç Anadolu Ormancılık Araştırma Enstitüsü Yayınları, Teknik Bülten No: 294. (in Turkish). 
Capinera JL, Barbosa P, 1975. Transmission of nuclear-polyhedrosis virus to gypsy moth larvae by Calosoma sycophanta. Ann Entomol Soc Am 68: 593-594. https://doi.org/10.1093/aesa/68.3.593.

de Boer JG, Harvey JA, 2020. Range-expansion in processionary moths and biological control. Insects 11(5): 267. https://doi. org/10.3390/insects11050267.

Demirözer O, Pekbey G, Hayat R, Herdoğan A, Acanski J, Milicic M, Uzun A, 2020. First contribution on distribution, abundance, and species richness of blowfly species (Diptera) of Isparta Province with five new records for the Turkish fauna. Turk J Zool 44:69-79. https://doi:10.3906/zoo-1909-6

Erkan N, 2018. Five-year results of the effect of pine beetle (Thaumetopoea wilkinsoni Tams) damage on redwood (Pinus brutia Ten.) Growth.. Ormancılık Araştırma Dergisi 5(2): 135-142. https://doi.org/10.17568/ogmoad.430501

Er MK, Tunaz H, Gokce A, 2007. Pathogenicity of entomopathogenic fungi to Thaumetopoea pityocampa (Schiff.) (Lepidoptera: Thaumetopoeidae) larvae in laboratory conditions. J Pest Sci 80: 235-239. https://doi.org/10.1007/s10340-007-0177-6.

Goertz D, Hoch G, 2013. Influence of the forest caterpillar hunter Calosoma sycophanta on the transmission of microsporidia in larvae of the gypsy moth Lymantria dispar. Agric For Entomol 15(2): 178-186. https://doi.org/10.1111/afe.12000.

Hodar JA, Castro J, Zamora R, 2003. Pine processionary caterpillar Thaumetopoea pityocampa as a new threat for relict Mediterranean Scots pine forests under climatic warming. Biol Conserv 110(1): 123-129. https://doi.org/10.1016/S00063207(02)00183-0.

Ince IA, Demir I, Demirbag Z, Nalcacioglu R, 2007. A cytoplasmic polyhedrosis virus isolated from the pine processionary caterpillar, Thaumetopoea pityocampa. J Microbiol Biotechnol 17(4): 632637.

İnal B, Kandemir I, 2020. DNA barcoding of black cherry aphid Myzus cerasi (Fabricus, 1775) (Hemiptera: Aphididae) populations collected from Prunus avium and Prunus cerasus. Turk J Zool 44: 146-155. https://doi.org/10.3906/zoo-1908-9.

Jacquet JS, Orazio C, Jactel H, 2012. Defoliation by processionary moth significantly reduces tree growth: a quantitative review. Ann For Sci 69: 857-866. https://doi.org/10.1007/s13595-012-0209-0.

Kanat M, Alma H, Sivrikaya F, 2005. Effect of defoliation by Thaumetopoea pityocampa (Den. \& Schiff.) (Lepidoptera: Thaumetopoeidae) on annual diameter increment of (Pinus brutia Ten.) in Turkey. Ann For Sci 62 (1): 91-94. https://doi.org/10.1051/ forest:2004095.
Kanat M, Özbolat M, 2006. Mass production and release of Calosoma sycophanta L. (Coleoptera: Carabidae) used against the pine processionary moth, Thaumetopoea pityocampa (Schiff.) (Lepidoptera. Thaumetopoediae) in biological control. Turk J Zool 30: 181-185.

Kuyulu A, Genç H, 2020. Genetic diversity of codling moth Cydia pomonella L. (Lepidoptera: Tortricidae) populations in Turkey. Turk J Zool 44(5): 462-471. https://doi.org/10.3906/zoo-2006-4.

Murillo R, Munoz D, Lipa JJ, Cabellero P, 2001. Biochemical characterization of three nucleopolyhedrovirus isolates of Spodoptera exigua and Mamestra brassicae. J Appl Entomol 125(5): 267-70. https://doi.org/10.1046/i.1439-0418.2001.00533.x.

Sidor C, Zamola B, Zega A, Dusanic L, 1982. A disease of pine processionary (Thaumetopoea pityocampa) caused by a nucleartype polyhedral virus. Redia 65: 89-96.

Takov DI, Ostoich PV, Tchorbanov Al, Pilarska DK, 2020. Order Diptera as a model in the studies of insect immunity: a review. Turk J Zool 44: 481-489. https://doi.org/10.3906/zoo-2006-11.

Trematerra P, Colacci M, Sciarretta A, 2019. Mass trapping trials for the control of pine processionary moth in a pine woodland recreational area. J Appl Entomol 143(1-2): 129-136. https://doi. org/10.1111/jen.12578.

Tsankov G, Encheva L, Kaitazova P, 1979. A virus disease of larvae of the pine processionary moth, Thaumetopoea pityocampa. Gorskostopanska Nauka 16: 68-71.

Vasconcelos SD, Williams T, Hails RS, Cory JS, 1996. Prey selection and baculovirus dissemination by carabid predators of Lepidoptera. Ecol Entomol 21(1):98-104. https://doi. org/10.1111/i.1365-2311.1996.tb00271.x.

Yaman M, Algı G, Radek R, 2019. Morphological, ultrastructural and molecular identification of a new microsporidian pathogen isolated from Crepidodera aurata (Coleoptera, Chrysomelidae). Turk J Zool 43: 407-415. https://doi.org/10.3906/zoo-1902-4.

Yaman M, 2020. Transmission of Microsporidium sp. between different generations of Crepidopdera aurata (Coleoptera: Chrysomelidae). Turk J Zool 44: 248-253. https://doi.org/10.3906/ zoo-2003-32.

Zeddam JL, Cruzado JA, Rodriguez JL, Ravallec M, Subilette EC, 2003. A cypovirus from the South American oil palm pest Norape argyrrhorea and its potential as a microbial control agent. Biocontrol 48: 101-112. https://doi.org/10.1023/A:1021234700472.

Zhou Y, Qin T, Xiao Y, Qin F, Lei C, Sun X, 2014. Genomic and biological characterization of a new cypovirus isolated from Dendrolimus punctatus. PLoS One 9(11): e113201. https://doi.org/10.1371/ journal.pone.0113201. 